\section{КОНСОЛІДАЦІЯ ПОРТІВ ЯК \\ ВАЖЕЛЬ ЗРОСТАННЯ ЇХ ПРОДУКТИВНОСТІ}

PORT CONSOLIDATION AS A LEVER FOR PRODUCTIVITY GROWTH

\author{
KRAVCHENKO A., \\ PhD in Economics, Associate \\ Professor, \\ Azov Maritime Institute National \\ University "Odessa Maritime \\ Academy", \\ GUSAKOV S., \\ Post-graduate Student, Donetsk \\ State University of Management
}

У статті підкреслено необхідність збільшення продуктивності портів за рахунок консолідачії портів. Розглядаються обставини використання портів-хабів. Аналізуються чинники та показники продуктивності портів.

Ключові слова: продуктивність порту, консолідація портів, сухі порти, потужність крану, контейнерний термінал.

B cтатье подчеркнута необходимость увеличения производительности портов за счет их консолидации. Рассматриваются обстоятельства использования портов-хабов. Анализируются факторы и показатели производительности портов.

Ключевые слова: производительность порта, консолидация портов, сухие порты, мощность крана, контейнерный терминал.

The article emphasizes the need to increase port performance through port consolidation. Considered the circumstances of the use of port hubs. Factors and indicators of port performance are analyzed.

Keywords: port performance, port consolidation, dry ports, crane capacity, container terminal.

Постановка проблеми. Зростання вантажопідйомності контейнерних суден було високим з початку таких перевезень у 1956 році, і стало надалі прискорюватися останні два десятиліття. Перші контейнерні судна у 1950-1960-х роках мали місткість від 500 до 800 TEU. Набір інструментів реформування портів у галузі державно-приватної інфраструктури доводить, що частка світових контейнерних суден вантажопідйомністю понад 5000 TEU зросла 3 1\% у 1996 році. Контейнерні перевезення розширювались найшвидшими темпами із середньорічним рівнем 8,0\% між 1980 і 2018 рр. Збільшення середніх розмірів контейнерних суден, ймовірно, буде продовжуватися, оскільки воно пропонує значне зниження середньої вартості перевезення на контейнер. Збільшення розміру судна призвело до практики консолідації суднових заходів у меншу 
кількість портів. Це процес, відомий як «консолідація портів» або «раціоналізація портів», і він особливо поширений на міжнародних маршрутах, де економія від масштабу на морі найбільш очевидна.

Аналіз останніх досліджень та публікацій. Питання підвищення продуктивності портів часто попадає у коло досліджень науковців та практиків, оскільки мають велике значення в економіці кожної держави. Так, можна назвати таких науковців: Хетч М. [2], Тіпер А. [3], Ле Гріфін Х. [4], Касіпі М. [6], Лубула Г. [7] та інші. Вони характеризували показники продуктивності портів, наводили критичний аналіз. Але технічний розвиток у морській галузі, процеси глобалізації вносять свої корегування у діяльність портів. Отже, дослідження важелів продуктивності портів не втрачають своєї актуальності.

Метою статті є дослідження важелів зростання продуктивності порту.

Виклад основного матеріалу дослідження. Внутрішній вузол або сухий порт належить до внутрішнього пункту консолідації вантажів, який з'єднаний 3 портовим терміналом залізничним транспортом, баржами або вантажівками. Часто практики управління ланцюгами поставок інтегровані з глибоководним терміналом. Внутрішні вузли забезпечують альтернативний засіб швидкого забезпечення додаткової пропускної спроможності портів, що залишаються після консолідації. Для портів з обмеженою пропускною спроможністю землю для використання контейнерних терміналів можна, як правило, отримати швидше у внутрішній місцевості. Отримання додаткової землі в припортовому районі зазвичай потребує коштів і має екологічне навантаження. Внутрішні хаби збільшують використання пропускної спроможності припортових операцій, оскільки, як правило, більше земель доступно у внутрішніх місцях. Несуттєві елементи портових операцій можуть бути виконані у внутрішньому районі, а менеджерам контейнерних терміналів може бути надано додаткові площі для зменшення інтенсивності складування контейнерів, зменшення загальної кількості перевезень на контейнер та підвищення продуктивності терміналу. Тому внутрішні вузли повинні забезпечувати ефективний інструмент для підтримки продуктивності протягом усього процесу консолідації портів.

Щоб впоратись зі збільшенням обсягу вантажів необхідно визначити важелі зростання продуктивності портів. Отже, після раціоналізації, решта портів потребуватимуть високого рівня продуктивності та достатньої потужності, щоб забезпечити зростання.

Використання та інтеграція внутрішніх портів $\epsilon$ засобом швидкого забезпечення пропускної спроможності. Вони також дозволяють виконувати непродуктивні портові послуги далеко від морського порту. Враховуючи вимоги до розташування та інфраструктури внутрішнього вузла, вони можуть бути значно дешевшими та доступнішими порівняно зі створенням нових причалів та збільшенням територій (шляхом рекультивації) біля порту [1].

Оксфордський словник [2] визначає продуктивність як виробництво на одиницю зусилля або ефективність продуктивних зусиль. Тіпер А. та Уармк Н. [3] припускають, що продуктивність - це показник того, наскільки ефективно використовуються ресурси (такі як машини, комп'ютерне програмне забезпечення, земля та праця) для виробництва результатів.

Як було зазначено вище, контейнерний термінал складається 3 різних компонентів. Всі вони мають різні виробничі показники, операційну 
продуктивність i, отже, детермінантами продуктивності. Ле Гріфін $\mathrm{X}$. та Мурфі М. [4] підкреслюють, що продуктивність всього контейнерного термінала безпосередньо пов'язана 3 передавальними функціями контейнерного термінала, включаючи кількість та швидкість руху прибережних кранів, використання причального обладнання та продуктивність працівників, що працюють у прибережній зоні. Отже, кожен компонент є життєво важливим для загальної продуктивності порту. Однак проведений аналіз та звітність, як правило, обмежується або зосереджується лише на одному компоненті (наприклад, стивідорному).

У 2010 році група Tioga [5] підготувала звіт у рамках Програми співробітництва 3 обробки вантажів, яка $є$ державно-приватним партнерством, спонсорованим Морською адміністрацією Сполучених Штатів, 3 метою підвищення продуктивності вантажних компаній шляхом впровадження обробки вантажів, дослідження та розробок. Вони переглянули технічну та галузеву літературу, щоб визначити, як можна та як слід вимірювати продуктивність портів у Сполучених Штатах, та зібрали наявні дані у набір профілів морських терміналів. Вони намічають ряд різних показників продуктивності, включаючи TEU на гектар, TEU на причал, переміщення крана (TEU) на годину, час повороту судна та переміщення TEU або крана на людину / годину праці. Ці показники продуктивності використовуються різними портами, 3 різною інфраструктурою та комерційними драйверами. Касипі М. та Шах М. [6] наводять зведену таблицю показників продуктивності, які зазвичай використовуються в різних елементах контейнерного термінала:

Метою системи збору інформації про вантажні перевезення $\epsilon$ «надати детальне розуміння цього перевезення, включаючи обсяги, диспропорції при експорті/імпорті та спосіб внутрішнього транспорту, що використовується для перевезення вантажів до портів та назад» [3]. Контейнерні порти забезпечують кількість оброблених контейнерів (в одиницях), середню норму крану, швидкість судна, які безпосередньо порівнянні 3 австралійським бюро статистики, що звітує про продуктивність порту Австралії.

Проведені спостереження в порту Літтельтон Крайстчерч та ЦентрПорт Веллінгтон встановили:

- Загальна кількість контейнерних одиниць (на відміну від TEUs або FEU) - загальна кількість контейнерів, що обробляються, незалежно від того, чи це одиниці двадцяти футів або сорок футів (і двадцятифутовий, і сорокафутовий контейнери відповідають одній одиниці).

- Норма крана - середня кількість контейнерів, які обробляє один кран за кожну годину, коли він використовується для завантаження або вивантаження судна. Норма крана обчислюється діленням загальної кількості контейнерів, що обробляються, на витрачену норму крана. Цей захід виключає всі експлуатаційні та неробочі затримки, такі як вітер, кришки люків та кріплення.

- Коефіцієнт судноплавства - середня кількість контейнерів, що обробляються за годину, всіма кранами, що використовуються, за кожну годину, коли крани використовуються для завантаження або вивантаження судна. Судновий тариф виключає всі оперативні та неопераційні затримки. Він обчислюється множенням кранової швидкості на кран інтенсивність. 
Інтенсивність крана - це міра кількості кранів, що використовуються для завантаження або вивантаження судна.

- Швидкість роботи судна - середня кількість оброблених контейнерів за кожну годину зайнятості праці на причаленому судні - тобто загальна кількість оброблених контейнерів, поділена на час, що минув. Швидкість роботи судна включає всі експлуатаційні та неробочі затримки, а отже, зафіксований показник продуктивності, як правило, нижчий за показник швидкості судна.

- Швидкість крану - це показник середньої продуктивності контейнерних кранів у порту після врахування експлуатаційних та неробочих затримок у використанні кранів. Однак ставка крана не відображає продуктивність роботи контейнерного терміналу порту, який може використовувати два або більше кранів для завантаження та вивантаження контейнерів з судна. Ставки суден допомагають дати кращу загальну перспективу продуктивності контейнерів у порту.

Австралійська портова статистика окреслює подальші показники продуктивності портів, однак, «Міністерство транспорту Нової Зеландії вважає, що розгляд цих заходів дає хороший початковий огляд продуктивності контейнерів у портах Нової Зеландії». Бюро інфраструктури, транспорту та регіональної економіки урядового управління Австралії видає щоквартальні статистичні звіти «Ватерлінія». У звітах Waterline подано детальну інформацію про тенденції щодо продуктивності переробки контейнерів у п’яти основних австралійських контейнерних портах - Брісбені, Сіднеї, Мельбурні, Аделаїді та Фрімантлі, - а також у звітах Waterline представлені детальні тенденції щодо стивідорної продуктивності (продуктивність на судні) та витрат на імпорт та експорт контейнерів. Однак, на відміну від новозеландських тенденцій продуктивності, опублікованих Міністерством транспорту, звіти «Ватерлінія» також окреслюють продуктивність роботи на суші. Ці заходи включають середній час опрацювання вантажних автомобілів для кожного порту, кількість доступних слотів для бронювання транспортних засобів у порівнянні з кількістю використаної та в які періоди протягом дня та іншу нефінансову статистику.

Лубула Г. та Маларз А. [7] аналізують стивідорну продуктивність п'яти основних контейнерних портів Австралії з метою отримання кращого розуміння того, що зумовлює ефективність роботи окремого контейнерного порту. Вони прийшли до висновку, що між 2000 і 2009 роками у кожному 3 п'яти портів відбулися значні покращення як продуктивності праці, так і загальної факторної продуктивності. Вони також припускають, що стивідорні операції стали капіталомісткими загалом, і стивідорні операції у всіх п'яти портах також зазнали збільшення віддачі від масштабу протягом цього періоду.

Продуктивність новозеландських контейнерних портів добре порівнюється з австралійськими. Дослідження Міністерства транспорту [5] щодо показників продуктивності портів шести найбільших контейнерних портів Нової Зеландії дійшло до висновку, що «продуктивність контейнерних портів Нової Зеландії представляється принаймні порівнянною з австралійськими та іншими міжнародними портами, а в деяких випадках і кращою». Тауранга, безсумнівно, $\epsilon$ найбільш продуктивним портом Нової Зеландії, однак відносна продуктивність інших портів Нової Зеландії залежить від ефективності вимірювання 
продуктивності та стратегічних цілей, пропускної здатності контейнерів або обладнання, що використовується в кожному порту.

Висновки і перспективи подальших досліджень. Традиційно контейнерні порти розглядаються як місце для завантаження та зберігання контейнерів «основною функцією контейнерного термінала $\epsilon$ передача та зберігання контейнерів». Однак збільшення попиту на вантажні перевезення, зміни вимог споживачів та посилення конкуренції в порту призвели до інтеграції прибережної та приморської діяльності в порту, а порти стали пунктом консолідації для регіональної та світової торгівлі.

Три компоненти контейнерного термінала: набережна (крани та стивідор), експлуатація портової території та інтеграція наземного транспорту. Однак між цими трьома компонентами $є$ функції передачі. Приморський компонент відноситься до оперативного завдання завантаження або розвантаження контейнерного судна, завершеного крановою інфраструктурою та стивідорним персоналом біля узбережжя або місця пристані. Функція території полягає в організації та зберіганні контейнерів та інтеграції з експлуатаційними вимогами як на суші, так і на судні, використовуючи різні типи територій експлуатаційне обладнання та конфігурації штабелювання контейнерів. Приземна складова відноситься до зв'язку контейнерного термінала із наземним видом транспорту залізничним та автомобільним транспортом.

Аналіз продуктивності та звітність, як правило, обмежується або зосереджується на пристані або стивідорному компоненті, хоча, ефективність контейнерного терміналу залежить від широкого набору факторів, що впливають на окремі компоненти контейнерного терміналу, а не просто продуктивність набережних кранів. Порти, як правило, орієнтовані на продуктивність компоненту причалу, оскільки саме цей компонент приносить більшу частину доходу порту і $є$ інтерфейсом для клієнтів контейнерного порту (транспортні лініі).

Огляд літератури висвітлює два основні показники потенціалу. Потужність крана залежить від кількості доступних кранів, годин роботи крана та середньої продуктивності крана за годину. 3 іншого боку, потужність території залежить від кількості слотів для зберігання контейнерів та середньої норми обороту слотів. Однак зі збільшенням обсягу та використання потужності збільшене використання земельної площі означає складання контейнерів вище, зменшуючи експлуатаційну доступність та знижуючи продуктивність території. Це також призведе до зменшення вантажопідйомності кранів, якщо не збільшити робочу силу та обладнання території, щоб не відставати від експлуатаційних потреб причалу. Тому залежність між використанням потужності або обсягом та продуктивністю $є$ негативною - змінні рухаються в протилежних напрямках. Зв'язок між обсягом та продуктивністю може бути позитивним в необмежених умовах, якщо збільшені обсяги дозволяють отримати економію від масштабу.

Внутрішній вузол або сухий порт відноситься до внутрішнього пункту консолідації вантажів, який пов'язаний 3 портовим терміналом залізничним транспортом, баржами або вантажівками, часто коридором великої місткості та має практику управління ланцюгами поставок, інтегровану 3 глибоководним терміналом. Останнім часом внутрішні вузли розглядаються як засіб збільшення 
потужності та спосіб підвищення продуктивності, який простіший за традиційні заходи, такі як збільшення розміру території за допомогою меліорації земель або збільшення пропускної здатності кранів за рахунок дорогих закупівель набережних кранів. Отже, очікується, що пропускна спроможність об'єкта внутрішнього вузла матиме позитивний зв'язок 3 продуктивністю терміналу (оскільки обсяги внутрішніх концентраторів зростають, а також продуктивність терміналу) і негативний зв'язок з використанням пропускної спроможності терміналу (як пропускна здатність внутрішньої концентратор збільшує пропускну здатність, зменшує на терміналі).

\section{References:}

1. Auckland Regional Holdings. Long-term Optimisation of the New Zealand Port Sector. Discussion Paper. October 2009.

2. Hatch M. J. and Cunliffe A. L. Organization Theory, 2nd Edition, Oxford University Press. Oxford. 2006.

3. Tipper A. \& Warmke N. Adjusting productivity statistics for variable capacity utilisation: Working harder or hardly working? (Statistics, New Zealand Working Paper No 12-02). 2012. URL: www.stats.qovt.nz.

4. Le-Griffin H. D and Murphy M. Container Terminal Productivity: Experiences at the Ports of Los Angles and Long Beach. University of Southern California. February 2006.

5. The Tioga Group. Improving Marine Container Productivity: Development of Productivity Measures. Proposed Sources of Data and Initial Collection of Data from Proposed Sources. Prepared for Cargo Handling Cooperative Program. July 8. 2010.

6. Kasypi M., Shah M. and Mohammad. A productivity analysis of medium seaport container terminal. The I UP Journal of Supply Chain Management. Vol. X, No. 1. March 2013, pp. 26-43.

7. Lubulwa G., Lightfoot A., and Malarz A. Analysis of stevedoring productivity in Australia's five major container ports. Australian Transport Research Forum 2010 Proceedings 29 September - 1 October 2010.

It was emphasized that ports have become a consolidation point for regional and world trade, as there has been an increase in demand for freight, consumer demands have changed and competition in the port has intensified. Performance analysis and reporting are usually limited or focused on the berth or stevedoring component, although the efficiency of a container terminal depends on a wide range of factors. These factors affect the individual components of the container terminal, not just the performance of the embankment cranes. Ports are usually focused on the performance of the berth component, as this component generates most of the port's revenue and is the interface for container port customers.

The literature review highlights two main indicators of potential. Crane capacity depends on the number of available cranes, crane operating hours and average crane performance per hour. On the other hand, the capacity of the territory depends on the number of slots for storage of containers and the average rate of turnover of slots. It is emphasized that with the increase in volume and capacity utilization, increased land 
use means higher container assembly, reducing operational availability and reducing its productivity. It is proved that all this will reduce the load capacity of cranes, if you do not increase the manpower and equipment of the territory, so as not to lag behind the operational needs of the berth. Therefore, the relationship between power usage or volume and performance is negative - variables move in opposite directions. The relationship between volume and productivity can be positive in unlimited conditions, if increased volumes allow to obtain economies of scale.

An internal node or dry port refers to an internal cargo consolidation point that is connected to a port terminal by rail, barge, or truck. Recently, internal nodes have been seen as a means of increasing capacity and a way to increase productivity, which is simpler than traditional measures such as increasing the size of the area or increasing the capacity of cranes through expensive purchases of embankment cranes. Therefore, it is expected that the bandwidth of the internal node object will have a positive relationship with the performance of the terminal and a negative relationship with the use of the bandwidth of the terminal.

УДК 331.52.021

DOI: 10.35340/2308-104X.2020.89-4-15

\section{УПРАВЛІННЯ ПРАЩІВНИКАМИ «СРІБНОГО ВІКУ» \\ В ДЕРЖАВНИХ ОРГАНІЗАЦІЯХ}

\section{MANAGEMENT OF "SILVER AGE" EMPLOYEES IN GOVERNMENT ORGANIZATIONS}

\author{
СУЛЬЖЕНКО Л. С., \\ аспірант Інституту підготовки \\ кадрів Державної служби \\ зайнятості України, Державний \\ центр зайнятості, провідний \\ фахівець 3 питань зайнятості
}

\author{
SULZHENKO L., \\ Post-graduate Student, \\ Institute of Personnel Training \\ State Employment Service of \\ Ukraine
}

У статті автор розглядає особливості сприйняття працівниками «срібного віку» роботодавиями та співробітниками. Вказано основні підходи до оптимізачії впровадження професійного досвіду прачівників «срібного віку» в державній організації. Охарактеризовано особливості віково-орієнтованої державної організаиії та виявлено ризики, переваги та стратегії адаптації в умовах домінування в організації кількості прачівників «срібного віку».

Ключові слова: «срібний вік»; управління; урядова організація; стратегія; кадрова політика; орієнтачійний пункт.

В статье автор рассматривает особенности восприятия работников «серебряного возраста» работодателями и сотрудниками. Указаны основные подходы к оптимизации внедрения профессионального 